\title{
Impact of phosphorus and luminosity in the propagation, photochemical reactions and quality of Lippia alba (Mill.) N.E.Br. seedlings
}

\author{
Impacto del fósforo y luminosidad en la propagación, \\ reacciones fotoquímicas y calidad de plántulas de \\ Lippia alba (Mill.) N.E.Br.
}
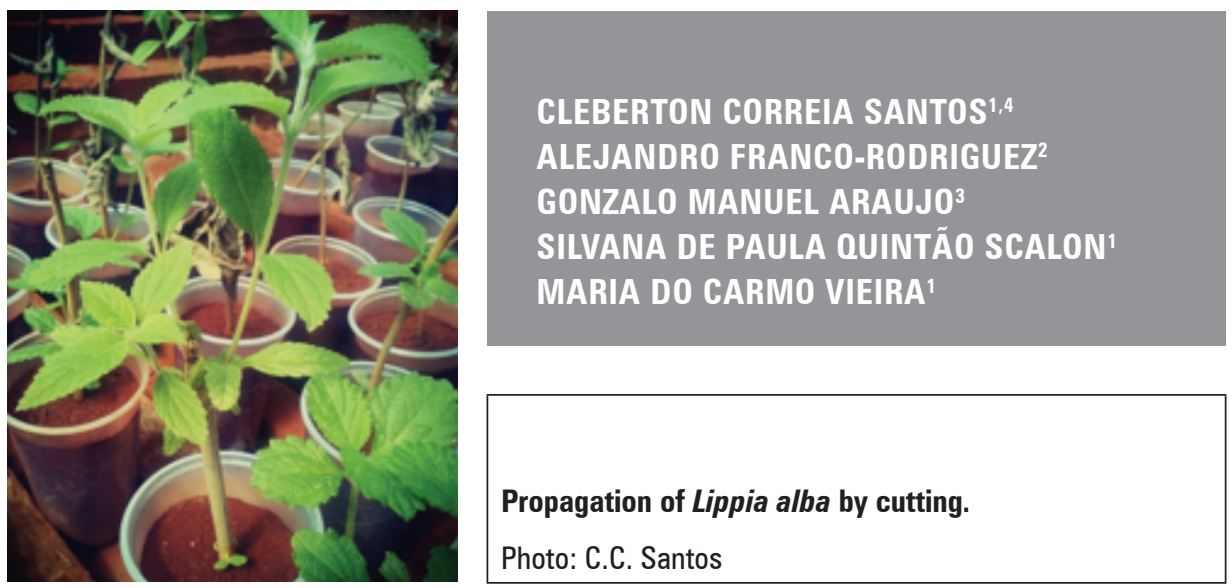

\section{ABSTRACT}

Lippia alba (Mill.) N.E.Br. (lemongrass) is a spice and medicinal plant species, with fledgling studies related to mineral nutrition and luminosity on foliar and vegetative responses. Thus, the aim of this study was to assess the foliar aspects and production of $L$. alba under two light conditions (full sun and $50 \%$ shading ) and four levels of phosphorus-P (0, 150, 300 and $\left.450 \mathrm{mg} \mathrm{kg}^{-1}\right)$. The L. alba seedlings presented changes in physiological indices and photochemical responses based on chlorophyll- $a$ fluorescence. The phosphate fertilization helped mitigate the light stress for the synthesis of chlorophylls. The greatest leaf biomass production occurred with addition of $\mathrm{P}$. The principal components analysis explained $74 \%$ of the variability, with leaf number, initial fluorescence and specific leaf area in principal component 1 (PC 1) and bud number, survival and leaf area in PC 2. Two groups formed in the cluster analysis, with lower distances between P300 full sun and P450 shading (2.31). The seedlings cultivated under full sun presented a higher survivability and seedling quality. The production of $L$. alba seedlings should be done under full sun with the addition of $450 \mathrm{mg} \mathrm{kg}^{-1}$ of phosphorus.

\footnotetext{
Additional key words: acclimatization; chlorophyll-a fluorescence; medicinal plant; mineral nutrition.

Federal University of Grande Dourados (UFGD), Faculty Agrarian Science, Dourados (Brazil). ORCID Santos, C.C.: 0000-0001-6741-2622; ORCID Scalon, S.P.Q.: 0000-0003-2024-7695; ORCID Vieira, M.C.: 0000-0001-7047-3848

2 Universidad Nacional del Nordeste (UNNE), Facultad de Ciencias Agrarias, Corrientes Capital (Argentina). ORCID Franco-Rodriguez, A.: 0000-0002-7766-7140

3 Universidad Nacional del Sur (UNNS), Facultad de Ciencias Agrarias, Buenos Aires (Argentina). ORCID Araujo, G.M.: 0000-0003-3961-2605

4 Corresponding author. cleber_frs@yahoo.com.br
} 


\section{RESUMEN}

Lippia alba (Mill.) N.E.Br. (hierba de limón) es una especie de interés medicinal y aromática, con estudios incipientes en relación a la nutrición mineral y a la luminosidad en las respuestas foliares y vegetativas. El objetivo del trabajo fue evaluar los aspectos foliares y la producción de plántulas de L. alba bajo dos condiciones de luminosidad (pleno sol y $50 \%$ de sombreamiento) y cuatro niveles de fósforo $\left(0,150,300\right.$ y $\left.450 \mathrm{mg} \mathrm{kg}^{-1}\right)$. Las plántulas presentaron alteraciones en los índices fisiológicos y respuestas fotoquímicas basadas en la fluorescencia de la clorofila- $a$. La fertilización fosfatada contribuyó en la mitigación del estrés luminoso en la síntesis de clorofilas. La mayor producción de biomasa de las hojas ocurrió con la adición de P. El análisis de componentes principales explicó el 74\% de la variabilidad donde fueron características representativas el número de hojas, la fluorescencia inicial y el área foliar específica dentro del componente principal 1 (PC 1) y el número de brotes, supervivencia y el área foliar en el PC 2. En el análisis de conglomerados, se constató la formación de dos grupos, con distancias más bajas entre 300 pleno sol y 450 sombreamiento (2.31). Las plántulas cultivadas a pleno sol presentaron mayor capacidad de supervivencia y

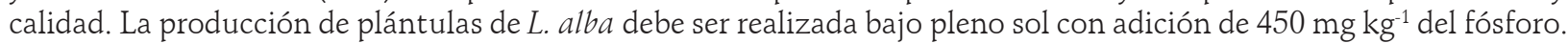

Palabras clave adicionales: aclimatización; fluorescencia de la clorofila-a; planta medicinal; nutrición mineral.

Received for publication: 24-05-2018 Accepted for publication: 31-07-2019

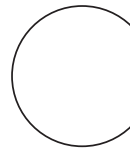

Lippia alba (Mill.) N.E.Br. (lemongrass, Verbenaceae) is a plant of medicinal interest, and tea made from its leaves has a soothing effect (Hohlenwerger et al., 2017). It can also be used as a natural preservative (Machado et al., 2011). The essential oil from its leaves has shown an antifungal activity against Aspergillus, Fusarium, Penicillium and Trichoderma (Glamočlija et al., 2011). There are few studies on cultivation practices that must be established during the production of seedlings propagated with stem cuttings.

The abiotic factors that may influence the vegetative propagation of seedlings include light availability in the cultivation environment, which may affect the morphophysiological responses of plants since it acts directly in the process of photochemical and biochemical reactions of photosynthesis (Leal et al., 2015).

However, light intensity may cause damage to the photosynthetic apparatus (Díez et al., 2017; Taiz et al., 2017) by changing the carboxylation speed of Ribulose 1.5 bisphosphate carboxylase/oxygenase, the assimilation of $\mathrm{CO}_{2}$ and, consequently, the production of photoassimilates for seedling formation. The plants have foliar functional strategies based on chlorophyll-a fluorescence in photosystem II (PS II), enabling the efficient use of light (Jaimez et al., 2018; Jiménez-Suancha et al., 2015). Therefore, these photochemical parameters may be used in assessing the integrity of photosynthetic machinery under ecophysiological disorders as a result of light stress.

In addition to light, another limiting factor for plants is soil in tropical regions, such as soil in Cerrado, which is highly weathered, has high levels of iron and aluminum oxides, and has high acidity (Souza et al., 2013; Islas-Espinoza et al., 2014), limiting the availability of some nutrients, particularly phosphorus (P). Greater attention is required for the low availability in soil in the tropics because of the greater fixation in soil (Quesada et al., 2011; Gérard et al., 2016).

Generally, P-deficient plants may suffer damage in diffusive and non-diffusive processes of photosynthetic metabolic pathways through a reduction in consumption and regeneration of Rubisco and production of ATP and NADPH (Andrade et al., 2018), which may cause instability in the photochemical process in PS II. Thus, phosphate fertilization is an important agronomic practice since it may assist in photochemical stability (Carstensen et al., 2018) and biomass increases in plants (Kuwahara et al., 2016).

We tested the hypothesis that P may contribute to the production and quality of seedlings, mitigate damage and increase photochemical reactions in PS II under light stress. This study associated the mineral 
nutrition and the ecophysiology of the plants in order to assess the photochemical and vegetative response and quality of $L$. alba seedlings produced with stem cuttings under different light availability and phosphate fertilization.

\section{MATERIAL AND METHODS}

\section{Collection of plant material and preparation of cuttings}

This species was identified and a voucher was deposited at the Herbarium DDMS of the Federal University of Grande Dourados (UFGD), under number 5226. The collection of plant material was performed from plant matrices in the Horto de Plantas Medicinais $\left(22^{\circ} 11^{\prime} 43.7^{\prime \prime} \mathrm{S}\right.$ and $54^{\circ} 56^{\prime} 08.5^{\prime \prime} \mathrm{W}, 452 \mathrm{~m}$ a.s.l.) of UFGD, in good phytosanitary conditions. The cuttings were removed from the median portion of the branches, standardized as $20 \mathrm{~cm}$ in length, mean diameter of $2.45 \mathrm{~mm}$, and a pair of leaves at the apex; $1 / 3$ of the cuttings was buried in the substrate.

\section{Studied Factors and experiment design}

This experiment was performed from October to December of 2017 in the Faculty Agrarian Science (22 $2^{\circ} 11^{\prime} 43.7^{\prime \prime} \mathrm{S}$ e $54^{\circ} 56^{\prime} 08.5^{\prime \prime} \mathrm{W}, 452 \mathrm{~m}$ a.s.l.) of UFGD in Dourados, Mato Grosso do Sul, Brazil. The climate of the region is classified as Am (Alvares et al., 2013) with an annual average rainfall over $1,500 \mathrm{~mm}$. The factors consisted of two light conditions (full sun and $50 \%$ shading) and four levels of phosphorus in the form of simple superphosphate - $18 \%$ of $\mathrm{P}_{2} \mathrm{O}_{5}(0,150$, 300 and $\left.450 \mathrm{mg} \mathrm{kg}^{-1}\right)$. The treatments were displayed in a $2 \times 4$ factorial scheme, in randomized blocks, with four replicates. The experiment unit consisted of five $500 \mathrm{~mL}$ plastic containers, with one cutting each.

Shading was simulated using polypropylene black screen with $50 \%$ retention of light. The soil was classified as Dystroferric Red Latosol (Santos et al., 2018), clay texture, with the following chemical attributes: $\mathrm{pH} \mathrm{CaCl}=4.76 ; \mathrm{P}=0.5 \mathrm{mg} \mathrm{dm}^{-3} ; \mathrm{Ca}=1.04 \mathrm{cmol}_{c}$ $\mathrm{dm}^{-3} ; \mathrm{K}=0.06 \mathrm{cmol}_{\mathrm{c}} \mathrm{dm}^{-3} ; \mathrm{Mg}=0.12 \mathrm{cmol}_{c} \mathrm{dm}^{-3}$; $\mathrm{Al}=1.2 \mathrm{cmol}_{\mathrm{c}} \mathrm{dm}^{-3} ; \mathrm{H}+\mathrm{Al}=7.71 \mathrm{cmol}_{c} \mathrm{dm}^{-3} ;$ sum of bases $=1.22 \mathrm{cmol}_{\mathrm{c}} \mathrm{dm}^{-3}$; cation exchange capacity $=$ $8.93 \mathrm{cmol}_{c} \mathrm{dm}^{-3}$ and base saturation $=13.68$. No soil correction was performed. Base fertilization was performed in coverage with ammonium sulphate $(20 \% \mathrm{~N})$ and potassium chloride $\left(60 \% \mathrm{~K}_{2} \mathrm{O}\right)$. The cultivation practices consisted of daily irrigation at $70 \%$ of the substrate's field capacity.

\section{Chlorophyll-a fluorescence}

At 30 and 60 days after burial (DAB) of cutting, the emission of chlorophyll- $a$ fluorescence was assessed by subjecting the leaves to darkness for $30 \mathrm{~min}$, using leaf clips, between 8:00 and 10:00 am. The initial $\left(F_{0}\right)$ and maximum $\left(F_{m}\right)$ chlorophyll-a fluorescence and photochemical efficiency of photosystem II $\left(F_{v} / F_{m}\right)$ were measured under flash of $1,500 \mu \mathrm{mol} \mathrm{m}{ }^{-2} \mathrm{~s}^{-1}$ with a portable fluorometer (OS-30P; Opti-Sciences Chlorophyll Fluorometer, Hudson, NY). The variables fluorescence $\left(F_{v}=F_{m}-F_{0}\right)$, efficiency of absorbed energy conversion $\left(F_{v} / F_{0}\right)$, non-photochemical maximum yield $\left(F_{0} / F_{v}\right)$ and electron transport rate (ETR) were estimated (Baker, 2008).

\section{Quantification of photosynthetic pigments}

At $60 \mathrm{DAB}$, fully expanded leaves were collected, with $1 \mathrm{~g}$ macerated in $8 \mathrm{~mL}$ of acetone (80\%). Afterwards, the samples were centrifuged for $10 \mathrm{~min}$ at $3000 \mathrm{rpm}$, and the absorbance reading was taken at the wavelengths of 470, 645 and $663 \mathrm{~nm}$ using a spectrophotometer. The contents of chlorophylls $a, b$, total $(a+b)$ and carotenoids were estimated (Arnon, 1949; Lichtenthaler and Buschmann, 2001).

\section{Growth indicators}

After $65 \mathrm{DAB}$, the survival, length of the aerial part (distance from the collet to the inflection of the highest leaf), collar diameter - CD $( \pm 1.0 \mathrm{~cm}$ above the substrate level), leaf thickness, and number of buds and leaves were recorded. Seedlings were removed from the containers, washed and assessed for length of the largest root and rooted cuttings (emission of adventitious root of at least $5.0 \mathrm{~cm}$ ). The leaf area was also assessed (LA) using an area integrator (area meter LI-COR 3100 C; Licor, Lincoln, NE).

\section{Biomass, physiological and quality indices}

Fresh material from the aerial and root parts were submitted to forced air circulation in an oven at $60 \pm 5^{\circ} \mathrm{C}$ to obtain the dry mass. Using the data for the LA and leaves and total dry biomass (LDM and 
TDM, respectively), the physiological indices of leaf area ratio $(\mathrm{LAR}=\mathrm{LA} / \mathrm{LDM})$, specific leaf area and mass (SLA $=$ LA/TDM and SFM = LDM/TDM, respectively) were calculated (Benincasa, 2003). From the data for total dry biomass, height/diameter ratio (RHD) and aerial part/root ratio (APRR), the Dickson quality index (DOI) was estimated (Dickson et al., 1960).

\section{Statistical analysis}

The rooting and survival data were transformed into arcsine of $\sqrt{x}+0.5$ and subjected to normal distribution with the Shapiro-Wilk test for normalization. The data for chlorophyll- $a$ fluorescence were assessed in plots subdivided in time. All data were subjected to analysis of variance (ANOVA), and, when significant according to the F test, the averages were compared with Student's $t$ test for the luminosity and evaluation periods, along with regression analysis for phosphorus $(P \leq 0.05)$, using SISVAR.

Additional multivariate analysis of principal components was carried out with variance and co-variance arrays. A cluster analysis was also performed using the complete linkage method to describe the similarity between the factors, and the grouping was performed with the classical method using Euclidean distances.

\section{RESULTS}

The greatest seedling survival and collet diameter were observed under full sun (Fig. 1A and B). The greatest height/diameter ratio (RHD) occurred in the shaded seedlings (Fig. 1C). The leaf number (LN) was influenced by the factors independently, with higher amounts under the shaded environment (Fig. 1D), without adjustment to phosphate fertilization (Tab. 1).

The characteristics height, rooting, length of the largest root, stem fresh and dry mass, root fresh mass and total mass were not influenced by the factors $(P>0.05)$, with averages of $22.4 \mathrm{~cm}, 76 \%, 12.0 \mathrm{~cm}$, $2.22,1.04,0.96$ and $6.30 \mathrm{~g} /$ plant, respectively. The number of buds, chlorophyll $b$ and fresh and dry mass of the leaves were influenced only by phosphorus, in

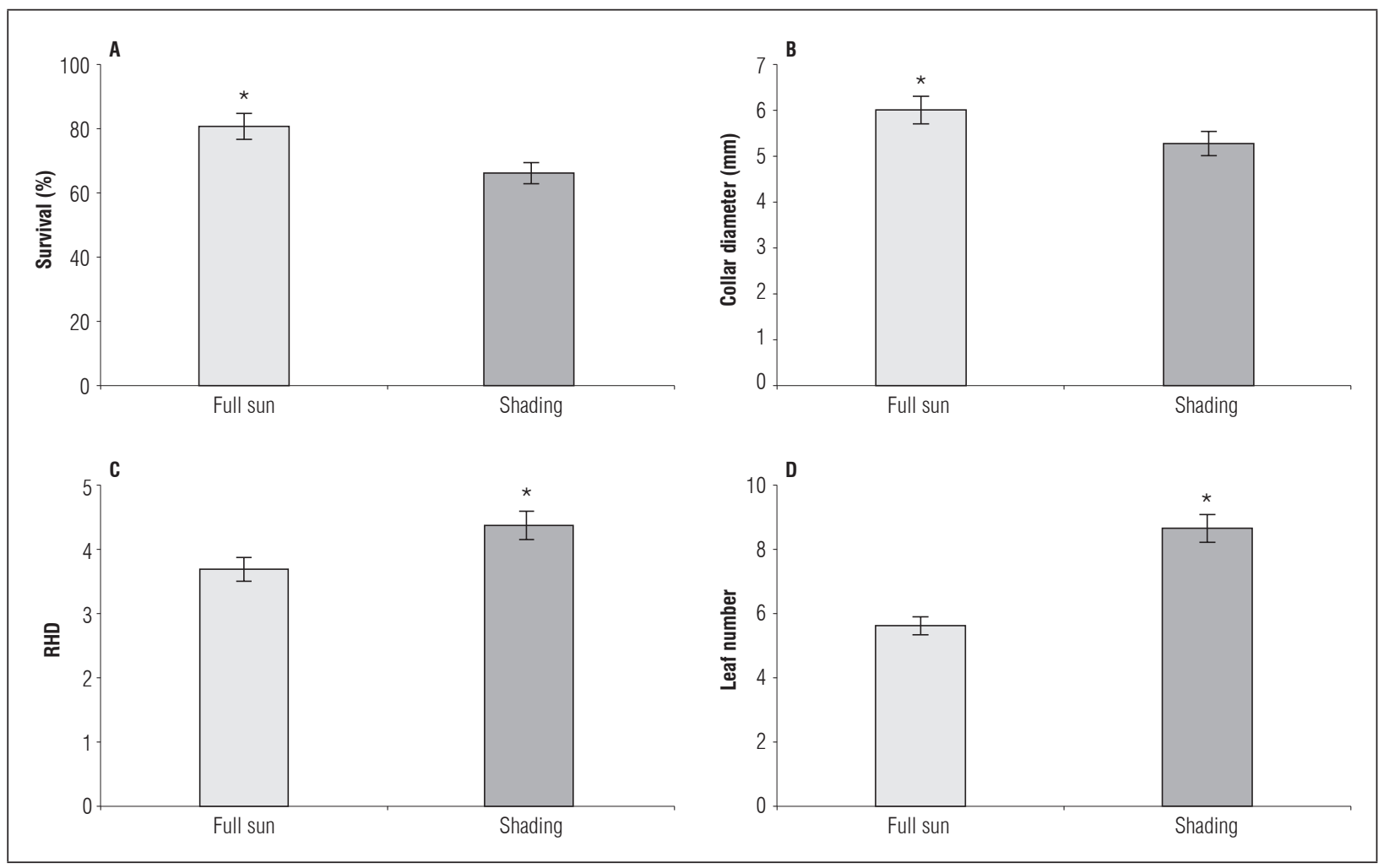

Figure 1. Survival (A), collar diameter (B), height/diameter ratio - RHD (C) and leaf number - LN (D) in $L$. alba seedlings produced under light ambience. * significant difference according to the Student's $t$ test $(P \leq 0.05)$. 
Table 1. Leaf and budding numbers, chlorophyll $b$, variable fluorescence, leaf fresh and dry mass in $L$. alba seedlings produced with different phosphorus doses.

\begin{tabular}{|c|c|c|}
\hline Characteristic & Equation & $\boldsymbol{R}^{2}$ \\
\hline Leaf number (LN) & $\hat{y}=\bar{y}=7.18$ leaves/plant & W/adjust \\
\hline Budding number (BN) & $\hat{y}=\bar{y}=6.34$ budding/plant & W/adjust \\
\hline Chlorophyll $b$ & $\hat{y}=\bar{y}=9.31 \mu \mathrm{g} \mathrm{cm}{ }^{2}$ & 0.98 \\
\hline Variable fluorescence & $\hat{y}=0.40832+0.00054^{*} P-0.00001^{*} P^{2}$ & 0.98 \\
\hline Leaf fresh mass & $\hat{y}=0.1564+0.0013^{*} P-0.00002^{*} P^{2}$ & 0.93 \\
\hline Leaf dry mass & $\hat{y}=0.14551+0.00079 * P$ & \\
\hline
\end{tabular}

* significant difference $(P \leq 0.05)$.

which the data for LN, NB and chlorophyll $b$ had no adjustment to the mathematical models (Tab. 1) because of the low value of the determination coefficient $\left(R^{2}\right)$.

Chlorophyll $a$ and total showed the same trend in the shaded environment, reducing the levels with increasing doses, with maximum levels (17.62 and $\left.28.19 \mu \mathrm{g} \mathrm{cm}^{2}\right)$ and minimum levels $(7.74$ and $10.21 \mu \mathrm{g}$ $\left.\mathrm{cm}^{2}\right)$ without and with $\left(450 \mathrm{mg} \mathrm{kg}^{-1}\right) \mathrm{P}$, respectively (Tab. 2). On the other hand, under full sun, chlorophyll $a$ and carotenoids had higher contents (9.96 and $1.84 \mu \mathrm{g} \mathrm{cm} \mathrm{cm}^{2}$, respectively) with the addition of 450 $\mathrm{mg} \mathrm{kg}{ }^{-1}$ of $\mathrm{P}$.

Under the shaded environment, the data for $F_{v} / F_{m}$ and $F_{0} / F_{v}$ had no adjustment to the mathematical models (Tab. 2). Under full sun, the highest ratio was 0.750 and 0.338 electrons quantum ${ }^{-1}$, under $450 \mathrm{mg}$ $\mathrm{kg}^{-1}$ of $\mathrm{P}$, respectively. The higher $F_{v} / F_{m}$ values were observed at $60 \mathrm{DAB}$ in full sun as a result of the lowest non-photochemical yield $\left(F_{0} / F_{v}\right)$ (Tab. 3). The greatest $F_{0}$ occurred in the leaves of shaded seedlings $\left(0.162\right.$ electron quantum $\left.^{-1}\right)$ (Fig. $\left.2 \mathrm{~A}\right)$ and at $30 \mathrm{DAB}$ (0.187 electrons quantum ${ }^{-1}$ ) (Fig. 2B).

The maximum $F_{v} 0.415$ electron quantum ${ }^{-1}$ was found with the addition of $27 \mathrm{mg} \mathrm{kg}^{-1}$ of $\mathrm{P}$ (Tab. 1). The shaded seedlings had higher $F_{v}$ and $F_{m}$ values at $30 \mathrm{DAB}$, with a reduction of values at $60 \mathrm{DAB}$ in both environments (Tab. 4). The ETR had lower values at $30 \mathrm{DAB}$ (Tab. 4). The greatest ETR occurred in the leaves of seedlings cultivated under full sun at 60 $\mathrm{DAB}$ as a result of the higher incident light.

In the shaded environment, the largest LA was 16.43 $\mathrm{cm}^{2}$ under $450 \mathrm{mg} \mathrm{kg}^{-1}$ of $\mathrm{P}$. Under full sun, the maximum leaf area $\left(11.85 \mathrm{~cm}^{2}\right)$ occurred in seedlings cultivated with $228.31 \mathrm{mg} \mathrm{kg}^{-1}$ of $\mathrm{P}$ (Tab. 5). The leaf
Table 2. Chlorophyll a, total chlorophyll, carotenoids, photochemical efficiency of the photosystem II $\left(F_{v}\right)$ $\left.\boldsymbol{F}_{m}\right)$, maximum non-photochemical yield $\left(\mathrm{F}_{0} / \mathrm{F}_{\mathrm{v}}\right)$ and efficiency of absorbed energy conversion $\left(F_{v} / F_{0}\right)$ in $L$. alba seedlings produced with phosphorus under light environment.

\begin{tabular}{|c|c|}
\hline \multicolumn{2}{|c|}{ Chlorophyll a $\left(\mu \mathrm{g} \mathrm{cm}^{-2}\right)$} \\
\hline Full sun & Shading \\
\hline$\hat{y}=5.57350+0.00975^{*} \mathrm{P}$ & $\hat{y}=17.64521-0.02201^{*} \mathrm{P}$ \\
$R^{2}=0.56$ & $R^{2}=0.90$ \\
\hline & \\
\hline
\end{tabular}

Total chlorophyll $(a+b)\left(\mu \mathrm{g} \mathrm{cm}{ }^{-2}\right)$

\begin{tabular}{|c|c|}
\hline Full sun & Shading \\
\hline$\hat{y}=\bar{y}=16.73$ & $\hat{y}=33.33526-0.05138^{*} \mathrm{P}$ \\
W/ adjust & $R^{2}=0.89$ \\
\hline
\end{tabular}

Carotenoids $\left(\mu \mathrm{g} \mathrm{cm}^{-2}\right)$

\begin{tabular}{|c|c|}
\hline Full sun & Shading \\
\hline$\hat{y}=0.58725+0.00279 * P$ & $\hat{y}=\bar{y}=1.51$ \\
$R^{2}=0.75$ & W/adjust \\
\hline
\end{tabular}

Photochemical efficiency of the photosystem II $\left(F_{v} / F_{m}\right)$

\begin{tabular}{|c|c|}
\hline Full sun & Shading \\
\hline $\begin{array}{c}\hat{y}=0.71932+0.00007^{*} P \\
R^{2}=0.57\end{array}$ & $\begin{array}{c}\hat{y}=\bar{y}=0.749 \\
\text { W/adjust }\end{array}$ \\
\hline \multicolumn{2}{|c|}{$\boldsymbol{F}_{0} / \boldsymbol{F}_{v}$ (electrons quantum ${ }^{-1}$ ) } \\
\hline Full sun & Shading \\
\hline $\begin{array}{c}\hat{y}=0.39187-0.00013^{*} \mathrm{P} \\
R^{2}=0.50\end{array}$ & $\begin{array}{c}\hat{y}=\bar{y}=0.337 \\
\text { W/adjust }\end{array}$ \\
\hline \multicolumn{2}{|c|}{$F_{v} / F_{0}$ (electrons quantum ${ }^{-1}$ ) } \\
\hline Full sun & Shading \\
\hline \multicolumn{2}{|c|}{30 DAB } \\
\hline$\hat{y}=2.0480+0.00192^{*} \mathrm{P}$ & $\hat{y}=\bar{y}=2.958$ \\
$R^{2}=0.80$ & W/adjust \\
\hline \multicolumn{2}{|c|}{60 DAB } \\
\hline$\hat{y}=\bar{y}=3.642$ & $\hat{y}=\bar{y}=3.261$ \\
W/adjust & W/adjust \\
\hline
\end{tabular}

${ }^{*}$ significant difference $(P \leq 0.05)$. 
Table 3. Photochemical efficiency of the photosystem II $\left(F_{v} / F_{m}\right)$ and maximum non-photochemical yield $\left(F_{0} / F_{v}\right)$ in $L$. alba seedlings produced with phosphorus under light environment, at 30 and 60 days after burial (DAB).

\begin{tabular}{|l|c|c|c|c|}
\hline \multirow{2}{*}{} & \multicolumn{3}{|c|}{$F_{v} / F_{\mathrm{m}}$} & $F_{0} / F_{v}$ \\
\cline { 2 - 5 } & $30 \mathrm{DAB}$ & $60 \mathrm{DAB}$ & $30 \mathrm{DAB}$ & $60 \mathrm{DAB}$ \\
\hline Environment & $0.699 \mathrm{aB}$ & $0.774 \mathrm{aA}$ & $0.438 \mathrm{aA}$ & $0.284 \mathrm{bA}$ \\
\hline Full sun & $0.740 \mathrm{aA}$ & $0.759 \mathrm{aA}$ & $0.353 \mathrm{aB}$ & $0.312 \mathrm{aA}$ \\
\hline C.V. (\%) & \multicolumn{3}{|c|}{11.37} \\
\hline
\end{tabular}

Means followed by the same lower case letter in the rows, for day after burial, and upper case in the columns, for light environment, do not differ according to the Student's $t$ test $(P \leq 0.05)$.

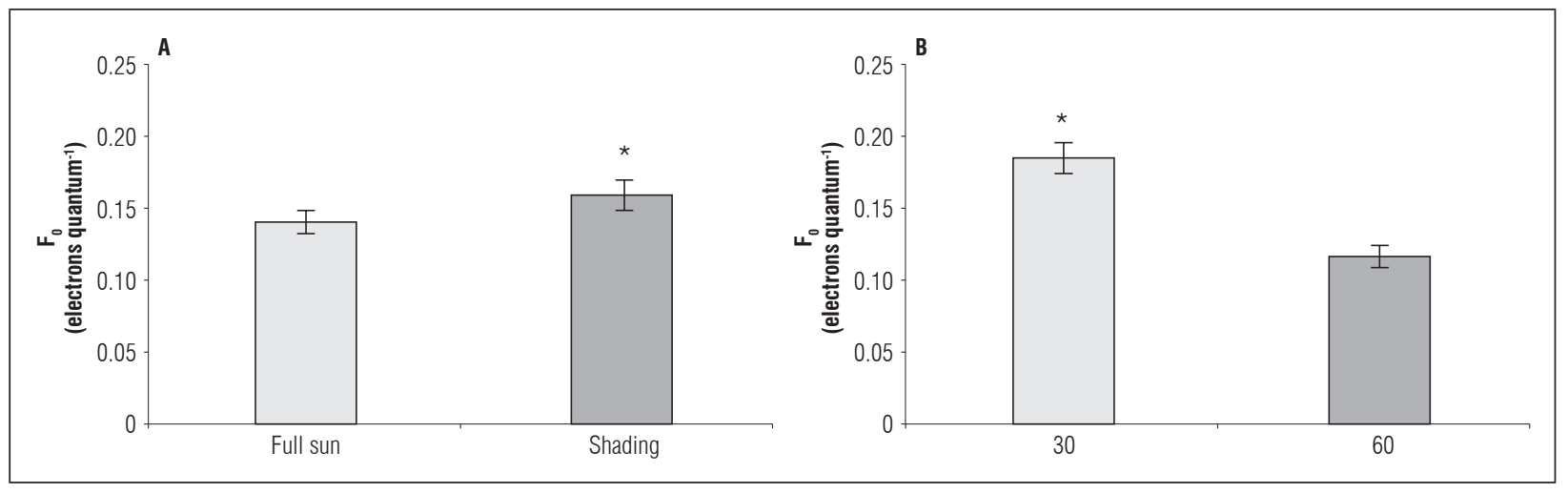

Figure 2. Initial fluorescence $-F_{0}$ in leaves of $L$. alba seedlings produced under phosphorus rates and light environment (a), at 30 and 60 days after burial $(b) .{ }^{*}$ significant difference according to the Student's $t$ test $(P \leq 0.05)$.

Table 4. Maximum $\left(F_{m}\right)$ and variable $\left(F_{v}\right)$ fluorescence and electron transport rate (ETR) in leaves of $L$. alba seedlings produced with phosphorus under light environment at $\mathbf{3 0}$ and $\mathbf{6 0}$ days after burial (DAB).

\begin{tabular}{|c|c|c|c|c|c|c|}
\hline \multirow{3}{*}{ Environment } & \multicolumn{2}{|c|}{$\mathrm{F}_{\mathrm{m}}$} & \multicolumn{2}{|c|}{$F_{v}$} & \multicolumn{2}{|c|}{ ETR } \\
\hline & \multicolumn{6}{|c|}{ (electrons quantum ${ }^{-1}$ ) } \\
\hline & 30 DAB & $60 \mathrm{DAB}$ & 30 DAB & 60 DAB & 30 DAB & 60 DAB \\
\hline Full sun & $0.611 \mathrm{aB}$ & $0.503 \mathrm{bA}$ & $0.433 \mathrm{aB}$ & $0.395 \mathrm{aA}$ & $248.38 \mathrm{bA}$ & $275.29 \mathrm{aA}$ \\
\hline Shading & $0.768 \mathrm{aA}$ & $0.543 \mathrm{bA}$ & $0.572 \mathrm{aA}$ & $0.415 \mathrm{bA}$ & $107.94 \mathrm{aB}$ & $110.78 \mathrm{aB}$ \\
\hline C.V. (\%) & \multicolumn{2}{|c|}{8.33} & \multicolumn{2}{|c|}{10.22} & \multicolumn{2}{|c|}{6.12} \\
\hline
\end{tabular}

Means followed by different lower case letters in a row, for day after burial, and upper case letters in the columns, for light environment, indicate significant differences according to the Student's $t$ test $(P \leq 0.05)$.

thickness data were not adjusted, and the sun leaves had higher values. The data for root dry mass and APRR of the seedlings under full sun were not adjusted to the mathematical models, but, under the shading, the higher mean values were $0.462 \mathrm{~g} /$ plant and
0.44 with $450 \mathrm{mg} \mathrm{kg}^{-1}$ of $\mathrm{P}$. The fresh and dry biomass of the leaves were influenced only by phosphorus, with higher values $(0.177$ and $0.0501 \mathrm{~g} /$ plant $)$ with the addition of 32.5 and $450 \mathrm{mg} \mathrm{kg}^{-1}$ of $\mathrm{P}$, respectively (Tab. 1). 
Table 5. Leaf area, thickness, root dry mass and aerial part/ root ratio in $L$. alba seedlings produced with phosphorus under light environment.

\begin{tabular}{|c|c|}
\hline \multicolumn{2}{|c|}{ Leaf area - LA } \\
\hline Full sun & Shading \\
\hline $\begin{array}{c}\hat{y}=7.68317+0.03653^{*} \mathrm{P} \\
-0.00008^{*} \mathrm{P}^{2} \\
R^{2}=0.86\end{array}$ & $\hat{y}=8.50657+0.01762^{*} \mathrm{P}$ \\
$R^{2}=0.72$ \\
\hline \multicolumn{2}{|c|}{ Leaf thickness $-\mathrm{LT}(\mathrm{mm})$} \\
\hline Full sun & Shading \\
\hline$\hat{y}=\bar{y}=0.33$ & $\hat{y}=\bar{y}=0.26$ \\
W/adjust & W/adjust \\
\hline \multicolumn{2}{|c|}{ Root dry mass - RDM (g per plant) } \\
\hline Full sun & Shading \\
\hline$\hat{y}=\bar{y}=0.537$ & $\hat{y}=0.21012+0.00056^{*} \mathrm{P}$ \\
W/adjust & $R^{2}=0.60$ \\
\hline \multicolumn{2}{|c|}{ Aerial part/root ratio - APRR } \\
\hline Full sun & Shading \\
\hline$\hat{y}=\bar{y}=0.093$ & $\hat{y}=0.03605+0.000{ }^{*} \mathrm{P}$ \\
W/adjust & $R^{2}=0.63$ \\
\hline
\end{tabular}

* significant regression $(P \leq 0.05)$
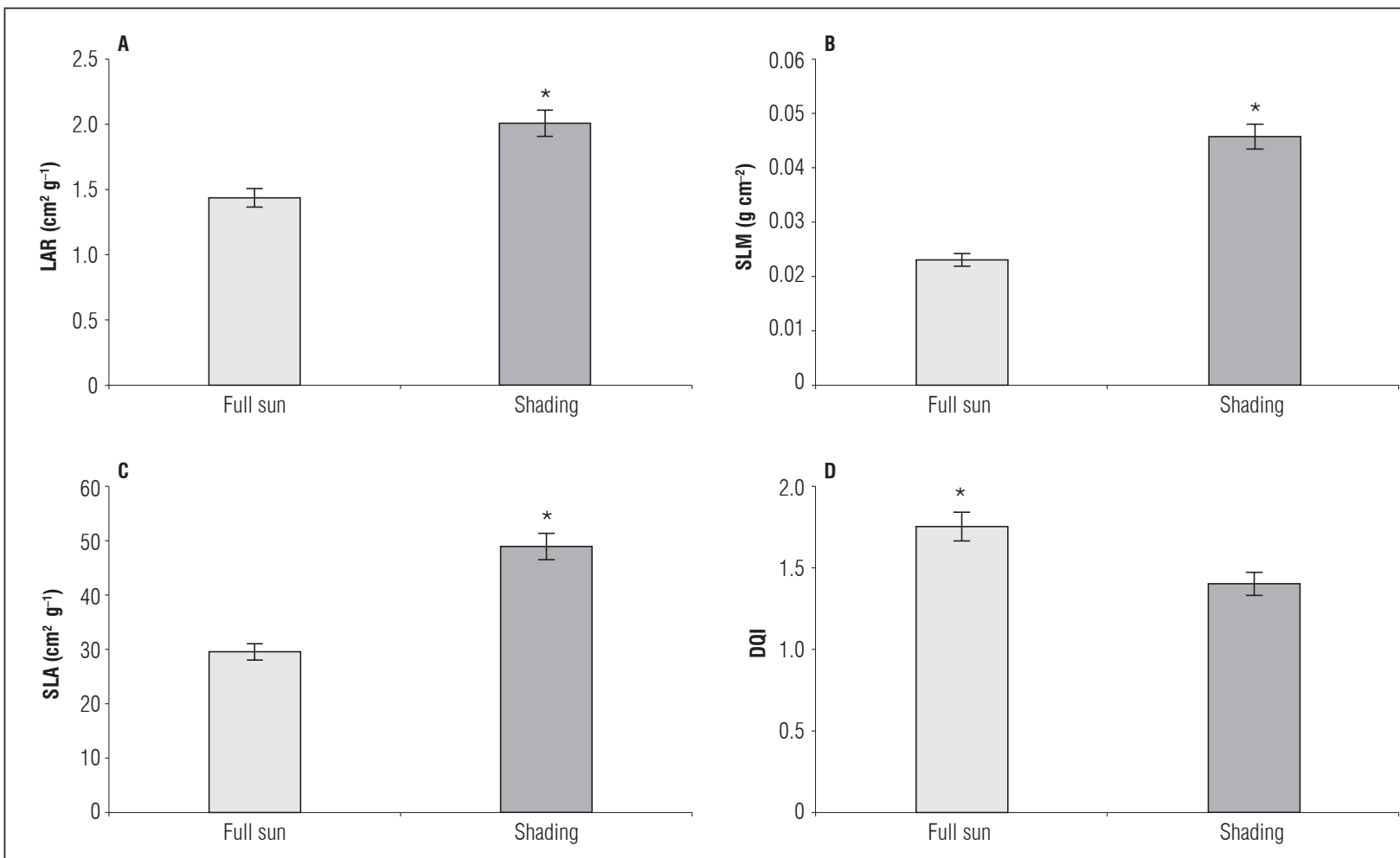

The greatest LAR $\left(2.027 \mathrm{~cm}^{2} \mathrm{~g}^{-1}\right)$ and SLM $(0.0458 \mathrm{~g}$ $\mathrm{cm}^{-2}$ ) occurred in the shaded seedlings (Fig. $3 \mathrm{~A}$ and $\mathrm{B}$ ) as a result of the greatest leaf thickness (Tab. 5). The greatest SLA was $48.54 \mathrm{~cm}^{2} \mathrm{~g}^{-1}$ in the seedlings produced in the shaded environment (Fig. 3C). For the DOI, the greatest value (1.70) was observed in the seedlings cultivated under full sun (Fig. 3D), regardless of phosphorus.

The principal components analysis explained 74\% of the variability, in which PC1 and PC2 contributed $41.05 \%$ and $32.05 \%$, respectively, of the remaining variance of the characteristics in the $\mathrm{L}$. alba seedlings (Fig. 4A). In the cluster analysis, two groups were formed for the P dose (G1 and G2), with six subgroups (Fig. 4B). The subgroups with lower distances between $\mathrm{P}$ dose and light environment ( $\mathrm{S}$ shading and PS - full sun) were 300 PS and $450 \mathrm{~S}$ (2.31), followed by $450 \mathrm{~S}$ and $450 \mathrm{PS}(4.61)$ and 300 $\mathrm{S}$ and $0 \mathrm{~S}(6.65)$.

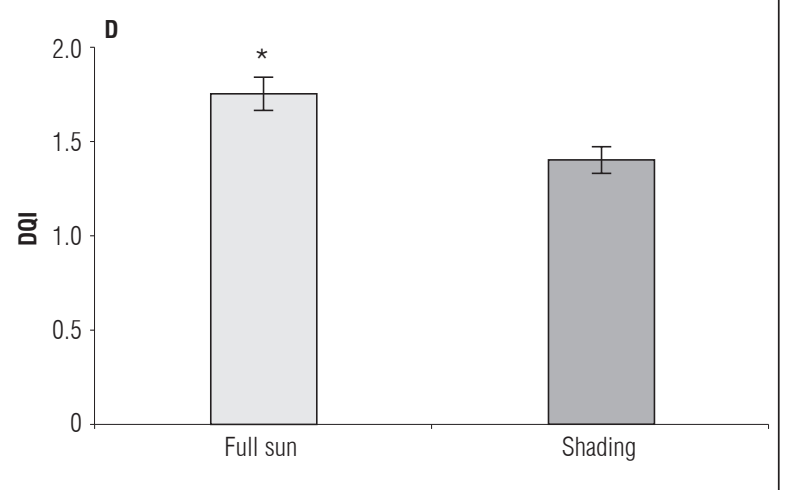

Figure 3. Leaf area ratio - LAR (A), specific leaf mass - SLM (B), specific leaf area - SLA (C) and Dickson quality index - D0I (D) in $L$. alba seedlings under light environment at 65 days after burial. *significant difference according to the Student's $\boldsymbol{t}$ test $(\boldsymbol{P} \leq \mathbf{0 . 0 5})$. 


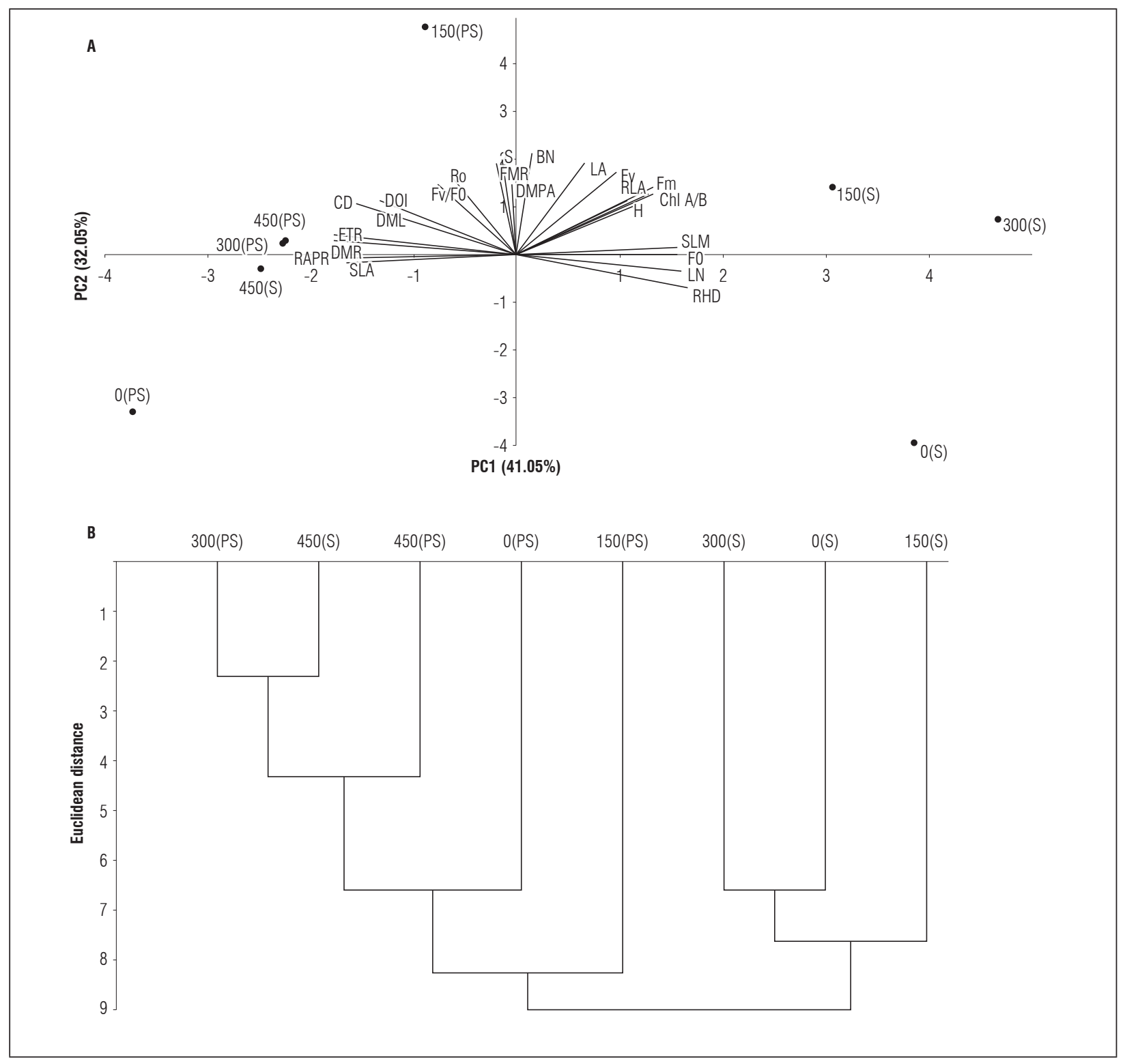

Figure 4. Principal components analysis (A) and dendrogram of similarity, based on Euclidean distances (B) of characteristics evaluated in the $L$. alba seedlings produced with phosphorus doses $\left(0,150,300\right.$ and $\left.450 \mathrm{mg} \mathrm{kg}^{-1}\right)$ and light environment (S - shading and PS - full sun).

\section{DISCUSSION}

The greatest survival was associated with the amount of photoassimilates as a function of greater incident light. Seedlings under excessive light lose more water through transpiration because of an increased temperature, with the greater diameter allowing a greater ability to transport water and photoassimilates to other organs in order to maintain turgidity (Taiz et al., 2017). The greatest RHD occurred in the shaded seedlings, but the values did not indicate that there was etiolation in the seedlings under limited light.

Generally, plants under shading tend to expand the number of leaf limbs, enabling greater light interception (Oliveira et al., 2017) and maximizing photosynthesis. These characteristics are important in the vegetative propagation of the species since the greater the amount of buds, the greater the formation of leaves, contributing to photoassimilate distribution to developing organs. 
The reduction of pigments, except carotenoids, in leaves under full sun can be explained by photoinhibition of chlorophylls as a result of excessive light (Fu et al., 2012). However, shaded leaves tend to increase the content of chlorophyll and, thereby, maximize the photosynthetic capacity (Díez et al., 2017). Similar results were observed by Soares et al. (2017) when assessing young Tamarindus indica L. plants under shading, which presented higher concentrations of chlorophylls.

An increase in chlorophyll content is desirable because it is responsible for capturing light photons and transmitting energy to reaction centers (Monteiro et al., 2018), and carotenoids are responsible for chlorophyll photoprotection and reduction of membrane harm (Taiz et al., 2017), maximizing the photosynthetic capacity. Under full sun cultivation, phosphate fertilization can be a potential mitigation strategy for ecophysiological disorders from light stress in the synthesis of chlorophylls.

$\mathrm{P}$, in the form of $\mathrm{Pi}$, is responsible for the control of enzymatic reactions and metabolic regulation in the cytosol and chloroplast (Hawkesford et al., 2012). Higher photochemical indicators, especially the $F_{v} /$ $\mathrm{F}_{\mathrm{m}}$ ratio, with phosphorus result because $\mathrm{P}$ favors the speed of ATP synthesis, contributing to the export of protons to the chloroplast stroma and thylakoid lumen (Carstensen et al., 2018), favoring the maintenance of electron mobility in PS II. Increasing $F_{d} /$ $F_{v}$ can be a photoprotective mechanism of the photosynthetic apparatus for excessive incident radiation (Blind et al., 2018), i.e. a greater use of electrons produced as a result of higher efficiency in absorbed energy conversion $\left(F_{v} / F_{0}\right)$, regardless of the shading level during this period (60 DAB) (Tab. 2).

The higher $F_{0}$ at $30 \mathrm{DAB}$ is desirable in order to mitigate damage in the photosynthetic apparatus (Fig. 2B). Fu et al. (2012) described a higher $F_{0}$ in Lactuca sativa $\mathrm{L}$. plants cultivated under $100 \mu \mathrm{mol} \mathrm{m}^{-2} \mathrm{~s}^{-1}$ (low irradiance) at the initial stage of the experiment, stating that this mechanism can mitigate an increase in reactive oxygen and D1 protein degradation. As for phosphorus in $F_{v}, \mathrm{P}$ is involved in phosphorylation reactions and pyrophosphate release, acting in the activation of catalytic enzymes, forming ATP (Hawkesford et al., 2012, Xing and Wu 2014; Andrade et al., 2018) and favoring photochemical stability because $F_{v}$ is related to the ability to transfer electrons.
The results for $F_{m}$ and ETR is important in the photochemical process since larger values favor the flow of chlorophyll molecules between acceptors in photosystems (Farias et al., 2016). The higher photochemical efficiency in PS II effectively contributes to maintaining the integrity of the photosynthetic apparatus and increasing vegetative characteristics.

Plants exposed to low luminosity enhance the expansion of leaves (Gondim et al., 2018) as a strategy for use of light. Increasing APRR and RDM may be associated with the fact that under high irradiance, substrate and leaves tend to lose more water through evapotranspiration and leaf transpiration. Thus, an increase in these characteristics under full sun promotes water absorption for the maintenance of metabolic processes and nutrient transport (Sarto et al., 2018).

The responses of plants to abiotic variants can change according to the species. Oliveira et al. (2017), when assessing the physiological and productive aspects of Origanum vulgare L. plants, found greater root biomass under shaded cultivation. On the other hand, there was greater biomass allocation in Physalis minima L. seedlings under full sun (Silva et al. 2016), similar to L. alba seedlings (Fig. 3).

P plays an important role in plant biomass allocation and is a structural component of nucleic acids, phospholipids and ATP formation, favoring primary metabolism reactions and constituting $\sim 0.2 \%$ of plant mass (Kuwahara et al., 2016). For seedling production in Dalbergia nigra Benth., it was found that the addition of $500 \mathrm{mg} \mathrm{kg}^{-1}$ of $\mathrm{P}$ favored an increase in biomass (Carlos et al., 2018), similar to the L. alba seedlings in this study (Tab. 1).

LAR and SLM show greater biomass allocation through leaf area with greater thickness (Oliveira et al., 2016). These authors found that Melissa officinalis L. plants, at $120 \mathrm{~d}$ after transplanting, showed a greater SLM when cultivated under full sun. For LAR, Ribeiro et al. (2018) found higher values in Pogostemon cablin cultivated under shaded conditions. The increase in SLA under this condition indicated the adaptive ability of leaf tissues in optimizing light capture (Guzmán et al., 2016; Liu et al., 2016) because it promotes $\mathrm{CO}_{2}$ assimilation and stomatal control (Gommers et al., 2013). However, leaves with a smaller thickness are less heavy. Similar results were observed in Enterolobium contortisiliquum (Vell.) Morong 
(Souza et al., 2017) and Colocasia esculenta L. Schott (Gondim et al., 2018). Both authors described higher values in plants under artificial shading.

The DOI demonstrated that this species has survivability and stability capacity when exposed to high irradiance, an important fact since the initial cultivation under this condition reduced the acclimatization period (rustification) of the seedlings, i.e. these will be less susceptible to weather under field conditions, such as excessive sunlight. The use of DOI has been constant when assessing seedling quality since it is an easy implementation analysis, performed by calculating the morphometric stability level, distribution and biomass allocation.

In PC 1, the characteristics that showed positive scores in descending order were RHD (0.271), LN (0.263), $F_{0}$ and SFM (0.255), and the characteristics with negative scores were APRR (-0.292), ETR and RDM (-0.288) and SLA (-0.270), which were the most similar. In PC 2 , the components that most contributed with positive factorial scores were the number of buds (0.352), survival (0.330), leaf area (0.319) and $F_{v}(0.289)$, with no negative absolute scores $>0.30$. The cluster analysis consisted of sample classification in order to verify the similarity within the groups and between-group heterogeneity, considering all evaluated characteristics (Araújo et al., 2013). Thus, there was greater heterogeneity between the luminous environments, with G1 comprising the association of $\mathrm{P}$ with shading, except for $450 \mathrm{~S}$ and G2 under full sun.

\section{CONCLUSION}

The Lippia alba seedlings responded positively to the phosphate fertilization when vegetative propagation was used with stem cuttings. The association of 450 $\mathrm{mg}$ of phosphorus with the cultivation under full sun contributed substantially to mitigating ecophysiological disorders in the photosynthetic apparatus as the result of light stress, providing greater photochemical stability, survival and quality in the Lippia alba seedlings. No acclimatization process was required.

\section{ACKNOWLEDGMENT}

The authors thank the National Council for Scientific and Technological Development (CNPq) and Coordination for the Improvement of Higher Education Personnel (CAPES) for granting scholarships and the
Foundation for Support to the Development of Education, Science and Technology of the State of Mato Grosso do Sul (FUNDECT) for financial support.

Conflict of interests: The manuscript was prepared and reviewed with the participation of the authors, who declare that there exists no conflict of interest that puts at risk the validity of the presented results.

\section{BIBLIOGRAPHIC REFERENCES}

Alvares, C.A., J.L. Stape, P.C. Sentelhas, J.L. de Moraes Gonçalves, and J.L. Sparovek. 2013. Köppen's climate classification map for Brazil. Meteorol. Z. 22(6), 711728. Doi: 10.1127/0941-2948/2013/0507

Andrade, F.H.A., W.E. Pereira, R.R. Morais, A.F. Silva, and M.A. Barbosa Neto. 2018. Effect of phosphorus application on substrate and use of saline water in sugar-apple seedlings. Pesqui. Agropecu. Trop. 48(2), 190-199. Doi: 10.1590/1983-40632018v4852035

Araújo, E.C., M.A. Uribe-Opazo, and J.A. Johann. 2013. Análise de agrupamento da variabilidade espacial da produtividade da soja e variáveis agrometeorológicas na região oeste do Paraná. Eng. Agríc. 33(4), 782-795. Doi: 10.1590/S0100-69162013000400018

Arnon, D.I. 1949. Copper enzymes in isolated chloroplasts: polyphenoloxidase in Beta vulgaris. Plant Physiol. 24(1), 1-15. Doi: 10.1104/pp.24.1.1

Baker, B. 2008. Chlorophyll fluorescence: a probe of photosynthesis in vivo. Ann. Rev. Plant Biol. 59, 8-113. Doi: 10.1146/annurev.arplant.59.032607.092759

Benincasa, M.M.P. 2003. Análise do crescimento de plantas (noções básicas). FUNEP, Jaboticabal, Brazil.

Blind, M.R., K.C.P. Costa, C.E.M. Silva, P.T.B. Sampaio, and J.F.C. Gonçalves. 2018. Fotossíntese de espécies Anibae em resposta à exposição a ambientes contrastantes de luz. Rodriguésia 69(2), 397-407. Doi: 10.1590/2175-7860201869211

Carlos, L., N. Venturin, R.P. Venturin, J.M. Alves, and P.R. Silva. 2018. Liming and phosphating in Dalbergia nigra (Vell.) Allemão ex Benth. seedlings. Floresta Ambient. 25(4), e20170239. Doi: 10.1590/2179-8087.023917

Carstensen, A., A. Herdean, S.B. Schmidt, A. Sharma, C. Spetea, M. Pribil, and S. Husted. 2018. The impacts of phosphorus deficiency on the photosynthetic electron transport chain. Plant Physiol. 3, 1-38. Doi: 10.1104/ pp.17.01624

Dickson, A., A.L. Leaf, and J.F. Hosner. 1960. Quality appraisal of white spruce and white pine seedling stock in nurseries. Forest. Chron. 36(1), 10-13. Doi: 10.5558/ tfc36010-1 
Díez, M.C., F. Moreno, and E. Gantiva. 2017. Effects of light intensity on the morphology and CAM photosynthesis of Vanilla planifolia Andrews. Rev. Fac. Nac. Agron. Medellín 70(1), 8023-8033. Doi: 10.15446/ rfna.v70n1.61736

Farias, M.E., E.G. Martinazzo, and M.A. Bacarin. 2016. Chlorophyll fluorescence in the evaluation of photosynthetic electron transport chain inhibitors in the pea. Rev. Ciênc. Agron. 47(1), 178-186. Doi: 10.5935/1806-6690.20160021

Fu, W., P. Li, and Y. Wu. 2012. Effects of different light intensities on chlorophyll fluorescence characteristics and yield in lettuce. Sci. Hortic. 135, 45-51. Doi: 10.1016/j. scienta.2011.12.004

Gérard, F. 2016. Clay minerals, iron/aluminum oxides, and their contribution to phosphate sorption in soiIs - a myth revisited. Geoderma 262, 213-226. Doi: 10.1016/j.geoderma.2015.08.036

Glamočlija, J., M. Soković, V. Tešević, G.A. Linde, and N.B. Colauto. 2011. Chemical characterization of Lippia alba essential oil: an alternative to control green molds. Braz. J. Microbiol. 42(4), 1537-1546. Doi: 10.1590/S1517-83822011000400041

Gommers, C.M.M., E.J.W. Visser, K.R.S Onge, L.A.C.J. Voesenek, and R. Pierik. 2013. Shade tolerance: when growing tall is not an option. Trends Plant Sci. 18(2), 65-71. Doi: 10.1016/j.tplants.2012.09.008

Gondim, A.R.O., M. Puiatti, F.L. Finger, and P.R. Cecon. 2018. Artificial shading promotes growth of taro plants. Pesqui. Agropecu. Trop. 48(2), 83-89. Doi: 10.1590/1983-40632018v4851355

Guzmán, J.A., R.A. Cordeiro, and E. Corea. 2016. Biomass allocation and gas exchange are affected by light conditions in endangered Cedrela salvadorensis (Meliaceae) seedlings. Rev. Biol. Trop. 64(3), 1143-1154. Doi: 10.15517/rbt.v64i3.19606

Hawkesford, M., W. Horst, T. Kichey, H. Lambers, J. Schjoerring, I.S. Møller, and P. White. 2012. Functions of macronutrients. pp. 135-189. In: Marschner, P. (ed.). Marschner's mineral nutrition of higher plants. $3^{\text {rd }} \mathrm{ed}$. Elsevier; Academic Press, Amsterdam. Doi: 10.1016/ B978-0-12-384905-2.00006-6

Hohlenwerger, J.C., B. Baldisserotto, R.D. Couto, B.M. Heinzmann, D.T. Silva, B.O. Caron, D. Schmidt, and C.E. Copatti. 2017. Essential oil of Lippia alba in the transport of Nile tilapia. Cienc. Rural. 47(3), e20160040. Doi: 10.1590/0103-8478cr20160040

Islas-Espinoza, M., L. Solís-Mejía, and M.V. Esteller. 2014. Phosphorus release kinetics in a soil amended with biosolids and vermicomposto. Environ. Earth Sci. 71(3), 1441-1451. Doi: 10.1007/s12665-013-2549-y

Jaimez, R.E., F.P. Amores, A. Vasco, R.G. Loor, O. Tarqui, G. Quijano, J.C. Jimenez, and W. Teraza. 2018.
Photosynthetic response to low and high light of cacao growing without shade in an area of low evaporative demand. Acta Biol. Colomb. 23(1), 95-103. Doi: 10.15446/abc.v23n1.64962

Jiménez-Suancha, S.C., O.H. Alvarado, and H.E. Balaguera-López. 2015. Fluorescencia como indicador de estrés en Helianthus annuus L. Una revisión. Rev. Colomb. Cienc. Hortíc. 9(1), 149-160. Doi: 10.17584/ rcch.2015v9i1.3753

Kuwahara, F.A., G.M. Souza, K.A. Guidorizi, C. Costa, and P.R.L. Meirelles. 2016. Phosphorus as a mitigador o the effects of water stress on the growth and photosynthetic capacity of tropical C4 grasses. Acta Sci. Agro. 38(3), 363-370. Doi: 10.4025/actasciagron.v38i3.28454

Leal, C.C.P., S.B. Torres, R.M.O. Freitas, N.W. Nogueira, and R.M. Farias. 2015. Light intensity and type of container on producing Cassia grandis L. f. seedlings. Rev. Bras. Eng. Agríc. Ambient. 19(10), 939-945. Doi: 10.1590/1807-1929/agriambi.v19n10p939-945

Lichtenthaler, H.K. and C. Buschmann. 2001. Chlorophylls and carotenoids: measurement and characterization by UV-VIS spectroscopy. Curr. Protoc. Food Anal. Chem. 1(Supl. 1). F4.3.1-F4.3.8. Doi: 10.1002/0471142913. faf0403s01

Liu, Y., W. Dawson, D. Prati, E. Haeuser, Y. Feng, and M. Kleunen. 2016. Does greater specific leaf area plasticity help plants to maintain a high performance when shaded? Ann. Bot. 118(7), 1329-1336. Doi: 10.1093/ aob/mcw180

Machado, T.F., M.F. Borges, and L.M. Bruno. 2011. Aplicação de antimicrobianos naturais na conservação de alimentos. Empresa Agroindústria Tropical, Fortaleza, Brazil.

Monteiro, D.R., H.F. Melo, C.M.T. Lins, P.R.M. Dourado, H.R.B. Santos, and E.R. Souza. 2018. Chlorophy11 a fluorescence in saccharine Sorghum irrigated with saline water. Rev. Bras. Eng. Agríc. Ambient. 22(10), 673-678. Doi: 10.1590/1807-1929/agriambi. v22n10p673-678

Oliveira, V.C., A.R. Santos, G.S. Souza, and R.M. Santos. 2017. Respostas fisiológicas de plantas de orégano (Origanum vulgare L.) cultivadas sob malhas coloridas e fertilizantes orgânicos. Rev. Colomb. Cienc. Hortic. 11(2), 400-407. Doi: 10.17584/rcch.2017v11i2.7591

Oliveira, G.C., W.L. Vieira, S.C. Bertolli, and A.C. Pacheco. 2016. Photosynthetic behavior, growth and essential oil production of Melissa officinalis L. cultivated under colored shade net. Chilean J. Agric. Res. 76(1), 123128. Doi: 10.4067/S0718-58392016000100017

Quesada, C.A., J. Lloyd, L.O. Anderson, N.M. Fyllas, M. Schwarz, and C.I. Czimczik. 2011. Soils of Amazonia with particular reference to the RAINFOR sites. Biogeosciences 8(6), 11415-11440. Doi: 10.5194/ bg-8-1415-2011 
Ribeiro, A.S.R., M.S. Ribeiro, S.K.V. Bertolucci, W.J.M. Bittencourt, A.A. Carvalho, W.N. Tostes, E. Alves, and J.E.B.P. Pinto. 2018. Colored shade nets induced changes in growth, anatomy and essential oil of Pogostemon cablin. An. Acad. Bras. Ciênc. 90(2), 1823-1835. Doi: 10.1590/0001-3765201820170299

Santos, H.G., P.K.T. Jacomine, L.H.C. Anjos, V.A. Oliveira, J.F. Lumbreras, M.R. Coelho, J.A. Almeida, J.C. Araújo Filho, J.B. Oliveira, and T.J.F. Cunha. 2018. Sistema brasileiro de classificação de solos. $5^{\text {th }}$ ed. Embrapa Solos, Rio de Janeiro, Brazil.

Sarto, M.V.M., D. Bessegio, C.A. Rosolem, and J.R.W. Sarto. 2018. Safflower root and shoot growth affected by soil compaction. Bragantia 77(2), 348-355. Doi: 10.1590/1678-4499.2017191

Silva, D.F., R. Pio, J.D.R. Soares, P.V. Nogueira, P.M. Peche, and F. Villa. 2016. The production of Physalis spp. seedlings grown under different-colored shade nets. Acta Sci. Agron. 38(2), 257-263. Doi: 10.4025/actasciagron.v38i2.27893

Soares, J.D.R., G.M.G. Dias, R.A.L. Silva, M. Pasqual, C.R.G. Labory, S.A. Asmar, and J.D. Ramos. 2017.
Photosynthetic pigments content and chloroplast characteristics of tamarind leaves in response to different colored shading nets. Aust. J. Crop. Sci. 11(3), 296-299. Doi: 10.21475/ajcs.17.11.03.p7906

Souza, J.P., N.M.J. Melo, A.D. Halfeld, and J.N. Reis. 2017. Shading effects on leaf life span and functional traits in the widespread species Enterolobium contorlisiliquum (Vell.) Morong. Acta Sci. Biol. Sci. 39(1), 113-122. Doi: 10.4025/actascibiolsci.v39i1.33400

Souza, N.H., M.E. Marchetti, T.O. Carnevali, D.D. Ramos, S.P.Q. Scalon, and E.F. Silva. 2013. Estudo nutricional de canafístula (I): crescimento e qualidade de mudas em resposta a adubação com nitrogênio e fósforo. Rev. Árvore. 37(4), 717-724. Doi: 10.1590/ S0100-67622013000400015

Taiz, L., E. Zeiger, I. Møller, and A. Murphy. 2017. Fisiologia e desenvolvimento vegetal. $6^{\text {th }}$ ed. Artmed, Porto Alegre, Brazil.

Xing, D. and Y. Wu. 2014. Effect of phosphorus deficiency on photosynthetic inorganic carbon assimilation of three climber plant species. Bot. Stud. 55, 60. Doi: 10.1186/s40529-014-0060-8 